\title{
FACTORS AFFECTING WITH THE PREVALENCE OF HYPERTENSION IN PREGNANCY: SCOPING REVIEW
}

\author{
Siti Yuriah*, Farida Kartini \\ Graduate Midwifery Department, Universitas Aisyiyah Yogyakarta, Siliwangi Street (Ring Road Barat) No. \\ 63 Mlangi, Sleman, Special Region of Yogyakarta. 55292, telp. (0274) 4469199 \\ *Corresponding author \\ Email: siti.yuriah.xia@gmail.com
}

\begin{abstract}
Background: Hypertension is a clinical term to describe the pressure of high blood which cause fetal morbidity due to reduced blood flow to the placenta, such as stunted fetal growth, fetal death in utero to premature birth to cause maternal morbidity such as pulmonary edema, bleeding in the brain, eclamptic seizures, blood clots in the veins, acute kidney failure and even death in the mother. Hypertension in Pregnancy is a major complication that causes $60 \%$ to $80 \%$ of maternal deaths and maternal morbidity in the worldwide. The purpose of this scoping review is to determine the factors that influence the incidence of hypertension in pregnancy.

Method: Scoping Review uses the following databases: Pubmed, Wiley Online Library, and ProQuest. Search results that meet the criteria will then be parsed into articles. Study Use of the Joana Briggs Institute/JBI and synthetic methods using transforming PEOS.

Results: From the 108 articles related to the title and abstract, 9 articles met the inclusion and exclusion criteria. Five factors were found, namely heredity, age, parity, gemeli and Body Mass Index/ BMI that affected Hypertension in Pregnancy.

Conclusion: Hypertension in pregnancy was $5-15 \%$ and it was a significant complication in pregnancy. Due to the etiology was still not clearly detected and the referral system was not definitely still perfect. It also indicated that five factors could affect the occurrence of hypertension in pregnancy which are, heredity, age, multiple pregnancies, parity, and body mass index.
\end{abstract}

\section{Keywords: Hypertension, Pregnancy, Pregnant Women}

\section{INTRODUCTION}

Pregnancy is a natural process beginning with the meeting of sperm cells and egg cells (fertilization), and it then continues with nidation and implantation to the time when the fetus is capable to grow and develop from outside the uterus $^{[1]}$. Pregnancy is also a physiological state. However, it frequently occurs in several conditions resulting in a high-risk pregnancy. One of the diseases that usually threaten pregnancy is Gestational Hypertension (hypertension in pregnancy). This disease can cause (1) fetal morbidity, triggered by the reduction of blood flow to the placenta, (2) fetal 
death, (3) stunted fetal growth in the womb, (4) premature birth and (5) maternal morbidity (such as acute kidney failure, eclamptic seizures, pulmonary edema, cerebral hemorrhage, and blood vessel clots occur) which can cause maternal death ${ }^{[2]}$.

Hypertension is a term to describe high blood pressure. Hypertension in pregnancy (Gestational Hypertension) happens when systolic blood pressure is greater (equal to $140 \mathrm{mmHg}$ ), and diastolic blood pressure is greater (equal to $90 \mathrm{mmHg}$ ). They are usually confirmed within four hours of measurement ${ }^{[11]}$. Gestational Hypertension is one of the major complications causing about $60 \%$ to $80 \%$ of all maternal deaths and maternal morbidity worldwide. The classification in Gestational Hypertension is Preeclampsia, Eclampsia, Gestational Hypertension, Chronic Hypertension and Preeclampsia superimposed on Chronic Hypertension. Women's life risk from pregnancy-related complications with hypertension is 14 times in developing countries than in developed countries. WHO data states that the causes of $80 \%$ of expectant mother experiencing death are postpartum bleeding (25\%), abortion (13\%), hypertension in expectant mother $(12 \%)$, obstructed labor $(8 \%)$, and other causes $(7 \%)^{[3]}$.

Globally, hypertension in pregnancy is a serious public health threat, both from developing and developed countries. Undoubtedly, this disease can cause death for babies born and mothers giving birth. It is due to the lack of typical signs and symptoms as a prior warning. Hypertension in pregnancy is a major cause of maternal and infant mortality and morbidity. According to an analysis from the World Health Organization (WHO), gestational hypertension is associated with $14 \%$ of maternal deaths, and it is the second leading cause of maternal death after hemorrhage in Sub-Saharan Africa and a contributor to $16.0 \%$ of maternal deaths in Sub-Saharan Africa ${ }^{[4]}$.
The cases of hypertension in pregnancy in Indonesia is the second most leading cause of maternal death after cases of bleeding. It means severe preeclampsia is the highest cause of hypertension in pregnancy, resulting in complications and causing death for the mother. In Indonesia, gestational hypertension rate is increasing, showing about $30 \%$ of mothers experiencing death ${ }^{[5]}$.

Several risk factors causing hypertension in pregnancy are having hypertension before the pregnancy, repeated pregnancies, family history of hypertension, kidney disease/disorder, diabetes, primigravida, weight gain during pregnancy (> $1 \mathrm{~kg} /$ week), and too old or too young reproductive age ${ }^{[6]}$. Prior identification of women who are at risk of hypertension in pregnancy is very necessary so that stricter supervision can be carried out as soon as possible ${ }^{[7]}$. The possibility of delivery by caesarean section increases in expectant mother with Gestational Hypertension. Similarly, the risk of placental abruption preterm birth low irth weight stillirth acute renal failure and intravascular coagulation have been observed more frequently in women with hypertensive disorders of pregnancy (Gestational Hypertension). Recent studies have demonstrated a higher risk of developing hypertension in pregnancy in women with a family history of hypertension, a history of hypertension due to a previous pregnancy, preexcitation diabetes, gestational diabetes mellitus, maternal age $\geq 40$ years, multiple pregnancies, nulliparity, and prepregnancy obesity. Several previous studies have found a higher pre-pregnancy body mass index is associated with an increased risk of gestational hypertension and pre-eclampsia. However, some studies have not observed this relationship. From several studies, it was found that excessive weight gain during pregnancy has been found as a risk factor for hypertensive disorders of pregnancy ${ }^{[8]}$. Therefore, many efforts to prevent and 
detect cases of hypertension in pregnancy have been carried out by the government, for instance, by carrying out integrated pregnancy tests.

Meanwhile, the service efforts that can be carried out by midwives are a form of health service efforts in improving health degrees consistently. Indicators of public health status can be identified from the number of Infant Mortality Rate (IMR) and Acute kidney injury (AKI). Data from ASEAN (Association of Southeast Asian Nations) states that the maternal mortality rate due to complications of pregnancy and childbirth is $14 / 100,000$ live births in Singapore, $62 / 100,000$ live births in Malaysia, $110 / 100,000$ live births in Thailand, $150 / 100,000$ live births in Vietnam, 230/100,000 live births in the Philippines, 380/100,000 live births in Myanmar and $420 / 100,000$ live births in Indonesia ${ }^{[18]}$. Considering that AKI and IMR in Indonesia are still high, they have become a priority issue in health services. Several efforts to reduce IMR due to hypertension can be done by performing prevention, early observation, and therapy ${ }^{[9]}$. Based on the description of the prevalence of hypertension in pregnancy, it is necessary to conduct a study of the results of several previous studies regarding the factors that can affect the prevalence of hypertension in expectant mother.

$\frac{\text { METHODS }}{\text { Research Problem Modification }}$

Table 1 Framework Research Question

\begin{tabular}{llll}
\hline $\boldsymbol{P}$ & \multicolumn{1}{c}{$\boldsymbol{E}$} & \multicolumn{1}{c}{$\boldsymbol{O}$} & \multicolumn{1}{c}{$\boldsymbol{S}$} \\
\hline Pregnant & Hyperten & Family & Original \\
Mother & sion & heredity, & research, \\
& Case & age, & published \\
& & multiple & from 2011- \\
& & pregnan & 2020, \\
& & cies, & qualitative \\
& & parity, & and \\
& & body & quantitative \\
& & mass & research \\
& & index & \\
\hline
\end{tabular}

Framework of Inclusion and Exclusion Criteria

Inclusion criteria for articles:

1) Articles are published in English and Indonesian.

2) Articles are published in 2011-2020.

3) These articles discuss several factors affecting the cases of hypertension in pregnancy.

4) There are no specific criteria for target countries.

Exclusion criteria for articles:

Opinion articles, review articles, reports and comments

\section{Article Search Flow}

Literature search utilizes articles for 20112020 limited to those using English and Indonesian, free full text, data for the last 9 years. Keywords must appear in the title/abstract. The articles used were from the PuMed electronic database, the Wiley Online Library, and ProQuest. Search was performed using keywords ((((("Factors") OR ("risk factors")) AND ("Hypertension")) OR ("hypertensive")) AND ("Pregnancy")) OR ("pregnant")) OR ("pregnant women"). Then the next stage is the selection of articles according to the criteria set by the researcher, and it is in accordance with the research questions. The articles appearing are then sorted until no similar article titles are found. Then sorted based on the inclusion and exclusion criteria that have been determined. The final result is the articles that will be analyzed.

\section{Article Extraction}

The obtained articles are then extracted. Extraction of articles by author, country, year, number of samples used, and search results performed and database items.

\section{Article Selection}

During an article search, 35 articles were from the PubMed database; 30 articles were identified from the Wiley Online Lirary database; and 43 articles were 
from the ProQuest database. After a review of all those articles were filtered based on relevance, there were 46 articles found. Next, Form those articles, a selection was done to find appropriate references about the factors affecting the prevalence of hypertension in pregnancy. Then there were 9 articles obtained. Those will be used for Scoping Review Research. The author considered the titles and abstracts of all articles to be used as inclusion criteria. Full text studies have been conducted and independently reviewed against these criteria. This therefore leaves 9 articles for final review.

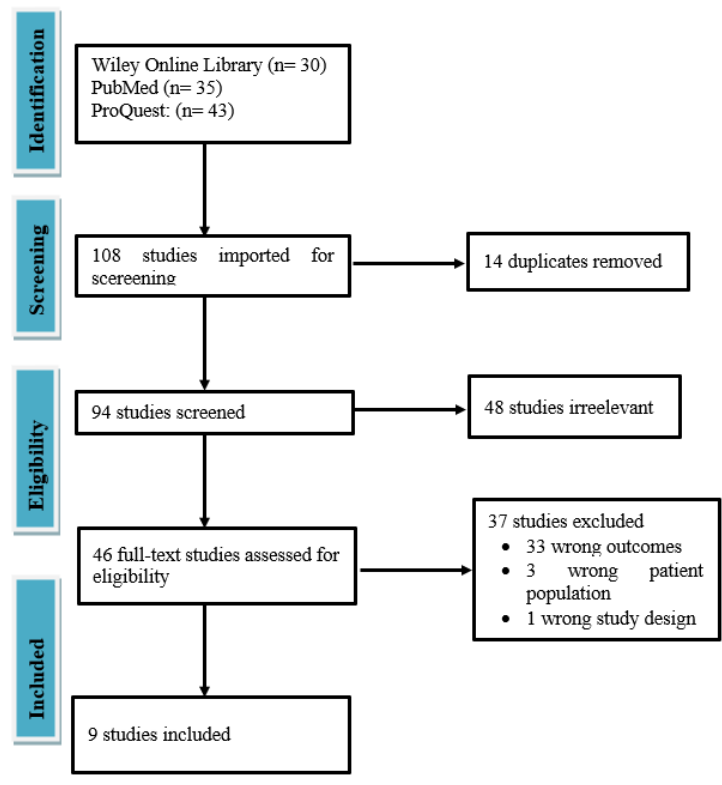

Figure I. Preparation steps based on PRISMA Chart

\begin{abstract}
RESULT
The identification results obtained from the search method in the online library of Wiley PuMed and ProQuest obtained up to 108 search results data. Finder contains selections including the results of the same search data and with the same search title. After the screening step, the inclusion step was carried out by matching the study data with the inclusion criteria set by the researcher, including the study of factors affecting the cases of hypertension in pregnancy in full text of articles from 2011-2020 obtained from international journals. The research results are collected and selected to include documents meeting the research criteria. The results showed there were 9 articles obtained that match the research criteria, and the process then continued to provide important reflections to get the best evidence on the frequency factor of hypertension in pregnancy from the research with the highest quality. The results of the study showed the factors affecting the prevalence of hypertension in pregnancy were heredity, age, grace, parity, and body mass index.
\end{abstract}

Table I. Article Extraction

\begin{tabular}{|c|c|c|c|c|}
\hline Author & Country & Year & Sample & Result \\
\hline $\begin{array}{l}\text { Subki et } \\
\text { al. }\end{array}$ & $\begin{array}{l}\text { West } \\
\text { Saudi } \\
\text { Arabia }\end{array}$ & 2018 & 9493 & $\begin{array}{l}\text { The themes raised from this research } \\
\text { were: Age, gravidity, parity, personal } \\
\text { and family history of hypertension, } \\
\text { obesity, and multigravida. }\end{array}$ \\
\hline Suleiman & Yordania & 2013 & 184 & $\begin{array}{l}\text { The themes raised in this research were: } \\
\text { family history of preeclampsia, diabetes, } \\
\text { high BMI, and nulliparity. }\end{array}$ \\
\hline $\begin{array}{l}\text { Walle \& } \\
\text { Azagew }\end{array}$ & Ethiopia & 2019 & 245 & $\begin{array}{l}\text { The themes raised in this research were: } \\
\text { maternal age, family history of } \\
\text { hypertension, and alcohol intake. }\end{array}$ \\
\hline
\end{tabular}




\begin{tabular}{|c|c|c|c|c|}
\hline $\begin{array}{l}\text { Muto et } \\
\text { al. }\end{array}$ & Japan & 2016 & 74 & $\begin{array}{l}\text { The themes raised in this research were: } \\
\text { nullipara and multipara, maternal age } 40 \\
\text { years, body mass index, In Vitro } \\
\text { Fertilization and Embryo Transfer (IVF- } \\
\text { ET), and family history of hypertension. }\end{array}$ \\
\hline $\begin{array}{l}\text { Zhou et } \\
\text { al. }\end{array}$ & China & 2015 & 84.656 & $\begin{array}{l}\text { The themes raised from this research } \\
\text { was: overweight/obese. }\end{array}$ \\
\hline $\mathrm{Hu}$ et al. & China & 2015 & $\begin{array}{l}373 \\
\text { hypertension } \\
\text { cases and } \\
507 \\
\text { normotensive } \\
\text { controls }\end{array}$ & $\begin{array}{l}\text { The themes raised in this study were: } \\
\text { family history of cardiovascular disease, } \\
\text { history of hypertension in pregnancy, } \\
\text { education level, poor relationship with } \\
\text { in-laws, increased Body Mass Index } \\
\text { (BMI), family history of hypertension, } \\
\text { smoking, and poor sleep quality. }\end{array}$ \\
\hline $\begin{array}{l}\text { Zhuang } \\
\text { et al. }\end{array}$ & China & 2019 & 99.535 & $\begin{array}{l}\text { The themes raised in this study were: } \\
\text { advanced maternal age, BMI, chronic } \\
\text { hypertension, and previous history of } \\
\text { hypertension. }\end{array}$ \\
\hline $\begin{array}{l}\text { Alves et } \\
\text { al. }\end{array}$ & Portugal & 2013 & 6.952 & $\begin{array}{l}\text { The themes raised in this study were: old } \\
\text { age, low level of education, history of } \\
\text { cardiovascular disease, overweight } \\
\text { before and during pregnancy, as well as } \\
\text { primiparas and multiparas. }\end{array}$ \\
\hline $\begin{array}{l}\text { Hinkosa } \\
\text { et al. }\end{array}$ & Ethiopia & 2020 & 6.826 & $\begin{array}{l}\text { The themes raised in this study were: age } \\
\geq 35 \text {, rural residential area, primigravida, } \\
\text { parity, history of abortion, multiple } \\
\text { pregnancies, lack of ANC, and history of } \\
\text { hypertension. }\end{array}$ \\
\hline
\end{tabular}

Women with a family history of

\section{DISCUSSION}

Family Heredity

Expectant mother with a family history of hypertension are more likely (eight times) to experience hypertensive disorders of pregnancy compared to those who do not. It is caused by genetic factors contributing to the physiological predisposition of hypertensive disorders of pregnancy ${ }^{[3]}$.

A family history of cardiovascular disease suggests the involvement of a genetic component in the multifactorial etiology of hypertensive disorders of pregnancy. Most of the genetic involvement is inferred based on a family history of hypertension ${ }^{[4]}$.

$$
\text { Women with gestational }
$$

hypertension and preeclampsia frequently reported a family history of stroke or cereral hemorrhage angina and myocardial infarction $^{[10]}$. hypertension are more likely to have a hypertensive disorder than women without a family history of hypertension. Many similar studies including in the Tigray region of Ethiopia found that a family history of chronic hypertension is a risk factor for hypertension in pregnant women $^{[11]}$.

It is in accordance with the research conducted by Denise Tiran (2011) in (Sinambela and Sari, 2018) stating that women who are at risk of developing hypertension during pregnancy include those who have a personal or family history of hypertension $^{[1]}$.

\section{Age}

Maternal age affects the reproductive process. In healthy reproduction, 20 to 35 years of age is considered as the securest 
age for pregnancy and childbirth. At that age, the reproductive organs are completely developed and can carry out their functions ${ }^{[12]}$.

According to research conducted by (Nurfatimah et al., 2020) maternal age and the development of reproductive organs are completely related. A healthy reproductive age is a safe reproductive age, which is between 20 to 35 years of age. If the expectant mother is $\leq 20$ years old, her reproductive organs are not biologically ready or mature. Furthermore, the unprepared expectant mother results in emotional instability so that the mother will become less concerned about the fetus she is carrying. For the expectant mother with an older age (> 35 years), it can increase the risk in their pregnancy. It is caused a decrease in the immune function of the reproductive system ${ }^{[5]}$.

Hypertension can increase at a young age, one of which is like immature or perfect organs of the expectant mother to reproduce. The cases of hypertension at a young age also tend to affect unstable psychological factors $^{[1]}$.

It is in line with a research conducted by (Ye et al., 2014), stating that women who are pregnant at the age of 2529 years have a lower risk of Gestational Hypertension than those aged 35-39 years. It is also in line with the study (Walle \& Azagew, 2019), respondents aged $<24$ years were $69 \%$ less likely to develop hypertension in pregnancy when compared to those aged $\geq 35$ years. Based on their research, it was stated that the risk of developing hypertension in pregnancy was more considerable in more elderly women than in young women in accordance with the results reported from a study conducted at Dessie Referral Hospital, Ethiopia. This is because an increase of age escalates the risk of cardiovascular disease $^{[3]}$.

\section{Multiple Pregnancies}

The risk of Gestational Hypertension in women with multiple pregnancies is $2-3$ times higher than that of women with singleton pregnancy in China ${ }^{[13]}$.

This research is similar to the research in Ethiopia showing multiple pregnancies had more than three times the development of hypertension during pregnancy compared to singleton pregnancy ${ }^{[11]}$.

According to the theory of placental ischemia, trophoblast material will be absorbed into the circulation, possibly increasing sensitivity to renin angiotensin II and aldosterone, arteriolar vasoconstriction and salt and water retention. According to the assumption of the researcher, there is a significant relationship between multiple pregnancies and preeclampsia, which is caused by the burden received by the uterus being 2 times that of a normal pregnancy ${ }^{[14]}$. Multiple pregnancies and the presence of diabetes mellitus are independent risk factors for the development of hypertension in pregnancy ${ }^{[15]}$.

\section{Parity}

Parity between two and three is a safe parity seen from the number of cases of maternal deaths. Higher parity can increase the cases of more maternal deaths. This can be reduced by family planning to suppress high parity. Therefore, pregnancies with high parity can be reduced ${ }^{[12]}$.

Parity contributes further to the development of hypertension in pregnancy, women having parity 0.3 are more likely to develop Gestational Hypertension than those who have given birth previously ${ }^{[13]}$.

It is in accordance with research conducted by (Nurfatimah et al., 2020), stating that one of the causes of the increased risk of hypertension in expectant mother, namely parity. Since childbirth occurs repeatedly, it has a high impact on the risk of future pregnancies ${ }^{[5]}$. 


\section{Body Mass Index (BMI)}

The method that can be used to identify the condition of overweight (obesity) in expectant mother is to use the body mass index (BMI) measurement method. If the BMI result is more than equal to $25 \mathrm{~kg} / \mathrm{m}$, it is declared to be obese or overweight for Asia Pacific. BMI is categorized as normal between 18.5 to $22.99 \mathrm{~kg} / \mathrm{m}$. When BMI score shows less than 18.5 $\mathrm{kg} / \mathrm{m}$, it is classified to underweight. Then, BMI score showing between 23 to $24.99 \mathrm{~kg} / \mathrm{m}$ are classified to overweight. Moreover, when BMI score is more than equal to $25 \mathrm{~kg} / \mathrm{m}$, it is classified to obese. The average BMI score occurring in preeclampsia is in the overweight group, with the score of $24.15 \mathrm{~kg} / \mathrm{m}$. In addition, those who are observed to be not in preeclampsia are in the normal group, with the score of $22.3 \mathrm{~kg} / \mathrm{m}$. The cases of severe and mild preeclampsia occurring at the end of gestational age were discovered to be higher, namely mothers with obesity or overweight ${ }^{[16]}$.

Obesity or being overweight or obese can increase the risk of gestational diabetes and gestational hypertension. It has been claimed that obesity can increase plasma concentrations of C-reactive protein, which is implicated in the etiology of hypertensive disorders of pregnancy increased in obesity ${ }^{[17]}$. Furthermore, some evidence has indicated obesity improves endothelial function and induces the systematic inflammatory response associated with atherosclerosis, which may play a role in women gaining excessive weight during pregnancy and being more likely to develop preeclampsia ${ }^{[8]}$. The risk of gestational hypertension is 1.8 times higher in overweight people and 3.1 times higher in obese people ${ }^{[13]}$.

The risk of gestational hypertension becomes higher with an increase in arm circumference and intake during pregnancy. Mid-arm circumference is the circumference of the left upper arm, measured at the midpoint of the distance from the acromion process of the shoulder to the end of the olecranon process of the mid-elbow. Women in the highest midarm circumference quintile $(28-39 \mathrm{~cm})$ were more likely (4.4 times) to develop preeclampsia than women in the lowest quintile $(21-23 \mathrm{~cm})^{[8]}$.

According to research of (Subki et al., 2018), obesity or being overweight or obese can increase the risk of gestational diabetes and gestational hypertension. It has een confirmed that oesity can increase plasma levels of C-reactive proteins which are implicated in the etiology of hypertensive disorders of pregnancy that increase oesity. Furthermore, some evidence has indicated obesity improves endothelial function and induces the systematic inflammatory response associated with atherosclerosis, which may play a role in women gaining excessive weight during pregnancy and being more likely to develop preeclampsia $^{[17]}$.

\section{CONCLUSION}

Based on the results of the Scoping Review and the discussion conducted by the researchers on the factors affecting the cases of hypertension in pregnancy, it can be concluded that there are five factors affecting the cases of hypertension in pregnancy, namely heredity, age, multiple pregnancies, parity, and body mass index (BMI). Health workers need distinguishing between early predictions (which is before signs and symptoms of disease are discovered) and early detection (which is the ability to discover abnormal diseases from the start). Health workers can provide preventive efforts for the expectant mother, namely through knowledge, understanding, and setting a healthy lifestyle.

\section{SUGGESTION}

For health workers, they can socialize factors that can be a risk for experiencing hypertension in pregnancy to expectant mother. Those factors are heredity, age, 
multiple pregnancies, parity, and body mass index (BMI). Health workers, especially midwives, can provide counseling about some of the risks of pregnancy with hypertension, increase quality in Antenatal Care (ANC), and provide counseling about balanced nutrition.

For the expectant mother, it is expected that they can always maintain a lifestyle by exercising regularly and maintain their pregnancy by checking their womb regularly to health workers to prevent and detect hypertension in pregnancy. In the end, If there is preeclampsia, a proper and fast treatment by health personnel and services can be carried out.

For families, it is expected for mothers and families to be more proactive in seeking information to increase mother's knowledge about signs and symptoms of pregnancy with hypertension and complications during pregnancy and childbirth. This information can be obtained through health workers, cadres, print media and television.

For further researchers, it can be used as a reference for future research. In addition, it is expected that they can carry out further research on the other factors that can affect the cases of the expectant mother with hypertension except what have been discussed in this study, such as heredity, age, multiple pregnancies, parity and body mass index.

\section{REFERENCES}

1. Sinambela, M., \& Sari, N. M. 2018. Faktor-Faktor Yang Mempengaruhi Hipertensi Pada Kehamilan Di Wilayah Kerja Puskesmas Pancur Batu Kecamatan Pancur Batu Kabupaten Deli Serdang Dari Bulan Januari Sampai Desember Tahun 2018. 1, 8.

2. Kaimmudin, L., Pangemanan, D., \& Bidjuni, H. 2018. Hubungan Usia Ibu Saat Hamil Dengan Kejadian
Hipertensi Di Rsu Gmim Pancaran Kasih Manado. 1, 5.

3. Walle, T. A., \& Azagew, A. W. 2019. Hypertensive disorder of pregnancy prevalence and associated factors among pregnant women attending ante natal care at Gondar town health Institutions, North West Ethiopia 2017. Pregnancy Hypertension, 16, 79-84. https://doi.org/10.1016/j.preghy.2019.0 3.007

4. Berhe, A. K., Ilesanmi, A. O., Aimakhu, C. O., \& Bezabih, A. M. 2020. Awareness of pregnancy induced hypertension among pregnant women in Tigray Regional State, Ethiopia. Pan African

Medical Journal,35.https://doi.org/10.11604/pa mj.2020.35.71.19351

5. Nurfatimah, N., Mohamad, M. S., Entoh, C., \& Ramadhan, K. (2020). Gambaran Faktor Risiko Kejadian Hipertensi dalam Kehamilan pada Ibu Hamil Trimester III: Overview of Risk Factors for Hypertension in Pregnancy among Third-Trimester Pregnant Women. Poltekita: Jurnal Ilmu Kesehatan, 14(1), 68-75. https://doi.org/10.33860/jik.v14i1.77

6. Imaroh et al. 2018. Faktor Risiko Yang Mempengaruhi Kejadian Hiperensi Pada Ibu Hamil di Wilayah Kerja Puskesmas Kedungmundu, Kota Semarang Tahun 2017. Jurnal Kesehatan Masyarakat. 6(1).

7. Lewandowska, M., Więckowska, B., Sajdak, S., \& Lubiński, J. 2020. PrePregnancy Obesity vs. Other Risk Factors in Probability Models of Preeclampsia and Gestational Hypertension. Nutrients, 12(9), 2681. https://doi.org/10.3390/nu12092681

8. Kazemian, E., Sotoudeh, G., DorostyMotlagh, A. R., Eshraghian, M. R., \& 
Bagheri, M. 2014. Maternal Obesity and Energy Intake as Risk Factors of Pregnancy-induced Hypertension among Iranian Women. 32(3), 9.

9. Lail, N. H. 2015. Faktor-Faktor Yang Behubungan Dengan Hipertensi Dalam Kehamilan Di Puskesmas Sukaraya Kecamatan Karang Bahagia Kabupaten Bekasi Tahun 2015. 41, 18.

10. Hu, R., Li, Y., Di, H., Li, Z., Zhang, C., Shen, X., Zhu, J., \& Yan, W. 2015. Risk factors of hypertensive disorders among Chinese pregnant women. Journal of Huazhong University of Science and Technology [Medical Sciences], 35(6), 801-807. https://doi.org/10.1007/s11596-0151510-6

11. Hinkosa, L., Tamene, A., \& Gebeyehu, N. (2020). Risk factors associated with hypertensive disorders in pregnancy in Nekemte referral hospital, from July 2015 to June 2017, Ethiopia: Casecontrol study. BMC Pregnancy and Childbirth, 20(1), 16. https://doi.org/10.1186/s12884-0192693-9

12. Bardja, S. 2017. Faktor-Faktor Yang Mempengaruhi Terjadinya Hipertensi Dalam Kehamilan Pada Ibu Hamil Di Puskesmas Gunung Jati Tahun. 2(11), 11.

13. Ye, C., Ruan, Y., Zou, L., Li, G., Li, C., Chen, Y., Jia, C., Megson, I. L., Wei, J., \& Zhang, W. 2014. The 2011 Survey on Hypertensive Disorders of Pregnancy (HDP) in China: Prevalence, Risk Factors, Complications, Pregnancy and Perinatal Outcomes. PLoS ONE, 9(6), e100180.https://doi.org/10.1371/journa 1.pone. 0100180

14. Apriyanti, F. 2014. Hubungan Kehamilan Gemeli Dan Paritas Ibu
Dengan Kejadian Preeklampsia Di Rsud Arifin Achmad Pekanbaru Tahun 2014. 9.

15. Kahsay, H. B., Gashe, F. E., \& Ayele, W. M. 2018. Risk factors for hypertensive disorders of pregnancy among mothers in Tigray region, Ethiopia: Matched case-control study. BMC Pregnancy and Childbirth, 18(1), 482. https://doi.org/10.1186/s12884018-2106-5

16. Andriani, C., Lipoeto, N. I., \& Indra Utama, B. 2016. Hubungan Indeks Massa Tubuh dengan Kejadian Preeklampsia di RSUP Dr. M. Djamil Padang. Jurnal Kesehatan Andalas, 5(1).https://doi.org/10.25077/jka.v5i1.4 64

17. Subki, A. H., Algethami, M. R., Baabdullah, W. M., Alnefaie, M. N., Alzanbagi, M. A., Alsolami, R. M., \& Abduljabbar, H. S. 2018. Prevalence, Risk Factors, and Fetal and Maternal Outcomes of Hypertensive Disorders of Pregnancy: A Retrospective Study in Western Saudi Arabia. Oman Medical Journal, 33(5), 409-415. https://doi.org/10.5001/omj.2018.7

18. Ruqaiyah, R. (2018). Faktor yang Berhubungan dengan Kejadian Hipertensi Pada Ibu Hamil di RSUD Haji Makassar Tahun 2018. Jurnal Kesehatan Delima Pelamonia, 2(1), 17.

https://doi.org/10.37337/jkdp.v2i1.51 